\title{
FIRST REPORT OF PSILORHYNCHUS BRACHYRHYNCHUS FROM INDIA WITH A NOTE ON FISHES OF BULLEDAM STREAM, MANIPUR
}

\author{
BUNGDON SHANGNINGAM", LAISHRAM KOSYGIN and SHIBANANDA RATH
}

Zoological Survey of India, Freshwater Fish Section, 27 J.L. Nehru Road, Kolkata (W.B.)

\begin{abstract}
Psilorhynchus brachyrhynchus Conway and Britz (2010) is reported for the first from India. The species is characteristic in having a short snout $(43-48 \% \mathrm{HL})$, the scale-less ventral surface between paired fins, and features of dorsal and caudal-fin pigmentation. A total of 14 species of fishes belonging to 12 genera under 7 families and 4 orders are recorded from the Bulledam stream of Manipur. The fish fauna of the stream is a mixture of endemic hillstream and Burmese forms.
\end{abstract}

Key words : Freshwater fish, Biodiversity, Conservation, Manipur.

\section{INTRODUCTION}

The torrent minnows of the genus Psilorhynchus McClelland are small cypriniform fishes with arched backs and flattened, frequently scale-less ventral surfaces. They inhabit fast-flowing rivers and streams in the foothills of the Himalayan, Indo-Burman and Western ghats mountain ranges (Rainboth,1983 and Arunachalam \& Muralidharan, 2008). Six species of Psilorhynchus viz., P.breviminor, P.chakpiensis, P.konemi, P.maculatus, P.microphthalmus, P.ngathanu and P.rowleyi are distributed in the Chindwin basin of Manipur (Shangningam and Vishwanath,2016).

The Bulledam is a hillstream of the Chakpi river which is a tributary of the Chindwin-Irrawaddy drainage and lies in the Indo-Burman region, one of the hottest biodiversity hotspots of the world. Ichthyologist has never surveyed the fish fauna of the Bulledam stream. The faunal inventory of the stream is far from accessibility owing to difficult hilly terrain, communication, transport problems and security reasons. There is no information about the fish fauna of the Bulledam stream. During a survey in the Chakpi river, four specimens of Psilorhynchus brachyrhynchus Conway and Britz (2010) were collected from the Bulledam stream and reported here for the first time from India.

\section{MATERIAL AND METHODS}

The present study thoroughly and critically examined each of the species collected. The fishes of the Bulledam stream were collected on $19^{\text {th }}$ May,2019 using local scoop nets and traps. The collected specimens were fixed in $10 \%$ formalin and preserved in ethanol. General measurements and counts follow Hubbs \& Lagler (1946) and Kottelat (2001). For Garra, Pethia, Psilorhynchus and Schistura, the methods of Kullander \& Fang (2004), Kullander (2008), Conway \& Kottelat (2010) and Kottelat (2001) were followed, respectively. Identification of species of the remaining genera followed Jayaram (1999). The specimens were also identified by comparing with type and other specimens in the Zoological Survey of India, Kolkata (ZSI).

\section{RESULTS AND DISCUSSION}

Psilorhynchus brachyrhynchus Conway \& Britz (2010) (Fig.1 \& Table.1)

Common name : Torrent minnow

Material examined : ZSI FF 8221, 4 exs, 41.245 .0 mm SL : India, Manipur, Chandel district, Bulledam stream, a tributary of the Chakpi river (Chindwin-Irrawaddy), collected on $19^{\text {th }}$ May,2019, BD Shangningam.

Distribution : Ayeyarwaddy river drainage, Northern Myanmar; Manipur(Chindwin drainage), India.

IUCN status : Data Deficient(DD).

The Bulledam stream, an important tributary of the Chakpi river, is located in the Indo-Burman biodiversity hotspot of the world. The biodiversity of the stream is characterized by high species richness, the occurrence of endangered, endemic and charismatic freshwater fish species of great interest. Many of them are important food fishes and are potential candidates as ornamental fishes. Interestingly, the stream is home to the freshwater hill-stream fish of taxonomic interest with 14 species belonging to 12 genera under 7 families and 4 orders. Biodiversity assess a variety of life forms. A community with 50 species of fishes from just two families would be regarded as less diverse than a community with 50 species from 12 families, although the species richness would be the same (Kottelat,2001). The present study yielded 7 families in total which depicts the fish richness in the Bulledam stream.

Psilorhynchus brachyrhynchus is reported here for the first time from India (Fig.1). It was originally described by Conway and Britz (2010) from Ma Kyaww Wa Chaung and its tributary Nan Hto Chaung, Putao, Kachin State, Ayeyarwaddy river drainage, Myanmar. Our recent collection of fishes in the Bulledam stream, a tributary of the Chakpi river (Chindwin river drainage) in Manipur included specimens of Psilorhynchus which entirely agrees with the description of Psilorhynchus brachyrhynchus (Table.1). The species is characterized in having two branchiostegal rays; 
ventral surface between paired fins scale-less; 5 unbranched pectoral-fin rays; $10+9$ caudal-fin rays; 32-34 lateral-line scales; 5-7 indistinct round to squarish dark blotches on lateral sides of the body and caudal fin with a dark, irregular vertical bar across its center. Thus, the range of distribution of the species extends up to the Bulledam stream of Chakpi river, Chindwin drainage in Manipur.

The present study also highlights the fish diversity of the Bulledam stream. The region being purely isolated and hill stream results in hosting large numbers of endemic species. The type of habitat in the hill streams includes swiftly flowing with a gravel bottom, rocky bed substrate and numerous riffles. For much of the year, water is cool, clear, shaded and flow rates are high. However, heavy rain causes these streams to swell into muddy torrents suddenly many times, and this may continue only for a few hours. The ichthyofauna of the stream has never been surveyed by any ichthyologist. The fish fauna of the stream consists of mostly endemic hillstream and Burmese forms. A list of fourteen fish species collected from the Bulledam stream is provided in Table.2.

According to the IUCN red list assessment of eastern Himalayas (2010), the majority of threatened fishes are in the

Table. 1 Morphometric and meristic data of Psilorhynchus brachyrhynchus ZSI FF 8221.

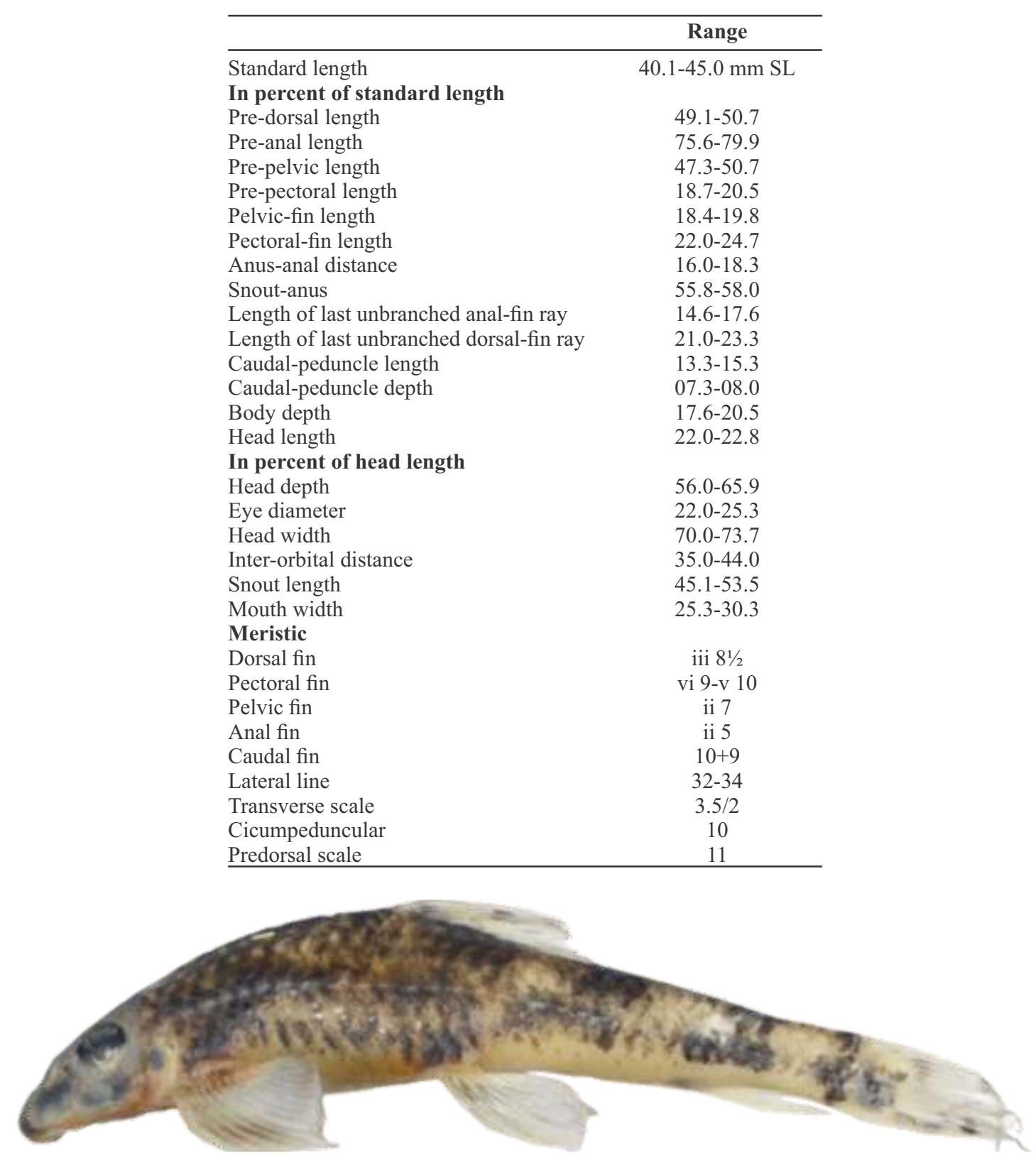

Fig. 1 Psilorhynchus brachyrhynchus. 
Table. 2 List of fishes collected from Bulledam stream.

\begin{tabular}{lll}
\hline S. Species & Family & Status \\
\hline 1. Barilius lairokensis (Arunkumar \& Tombi,2000) & Cyprinidae & Endemic to Chindwin Basin \\
2. Opsarius dogarsinghi (Hora,1921) & Cyprinidae & Endemic to Chindwin Basin \\
3. Pethia atra (Linthoinagmabi \& Vishwanath,2007) & Cyprinidae & Endemic to Chindwin Basin \\
4. Garra paralissorhynchus (Vishwanath \& Shanta,2005) & Cyprinidae & Endemic to Chindwin Basin \\
5. Garra namyaensis (Shangningam \& Vishwanath,2012) & Cyprinidae & Endemic to Chindwin Basin \\
6. Devario naganensis (Chaudhuri,1912) & Cyprinidae & Endemic to Chindwin Basin \\
7. Psilorhynchus brachyrhynchus (Conway \& Britz,2010) & Psilorhynchidae & First record to India \\
8. Pangio pangia (Hamilton,1822) & Cobitidae & Widely distributed \\
9. Mustura prasadi (Hora,1921) & Nemacheilidae & Endemic to Chindwin Basin \\
10. Schistura kangjupkhulensis (Hora,1921) & Nemacheilidae & Endangered species \\
11. Schistura khugae (Vishwanath \& Shanta,2004) & Nemacheilidae & Endemic to Chindwin Basin \\
12. Glyptothorax ventrolineatus (Vishwanath \& Linthoingambi,2006) & Sisoridae & Endemic to Chindwin Basin \\
13. Mastacembelus armatus (La Cepede,1800) & Mastacembelidae & Widely distributed \\
14. Channa gachua (Hamilton,1822) & Channidae & Widely distributed \\
\hline
\end{tabular}

Chindwin Basin in Manipur. The Bulledam stream is a small hill stream inhabited threatened and endemic fishes. The endangered fish species, Schistura kanjupkhulensis is found in the stream. However, due to various anthropogenic activities like Jhum cultivation, dynamiting, overexploitation etc., the fish fauna of the stream and their ecosystem is threatened. In view of the rich fauna, more studies are needed to understand the biology, population trend, nutritional quality etc. to categorize them in respect of threat criteria, value for farm culture etc. At the same time, more surveys are required to assess the rich diversity of the region.

\section{ACKNOWLEDGMENT}

We are grateful to Dr. Kailash Chandra, Director, Zoological Survey of India for permission to undertake the present study.

\section{REFERENCES}

Arunachalam, M. and Muralidharan, M. (2008). Description of a new species of the genus Psilorhynchus (Teleostei : Psilorhynchidae) from a Western ghats stream in Southern India. Raffles Bulletin of Zoology, 56 : 405-414.

Conway, K. W. and Kottelat, M. (2010). Two new species of torrent minnow (Ostariophysi : Psilorhynchidae) from Western Myanmar. The Raffles Bulletin of Zoology, $58: 259-267$.

Conway, K. W. and Britz, R. (2010). Three new species of Psilorhynchus from the Ayeyarwaddy river drainage, Myanmar (Teleostei : Psilorhynchidae). Zootaxa, 2616:31-47.

Hubbs, C. L. and Lagler, C. F. (1946). Fishes of the great lakes region. Cranbrook Instt. Science, 26 : 1-186.

Jayaram, K. C. (1999). The freshwater fishes of Indian region. Narendra Publ. House, New Delhi, p. 551.

Kottelat, M. (2001). Fishes of Laos. WHT Publications (Pvt.) Ltd., pp. 1-198.

Kullander, S. O. (2008). Five new species of Puntius from Myanmar (Teleostei : Cyprinidae). Ichthyological Exploration of Freshwaters, 19(1): $59-84$.

Kullander, S. O. \& Fang, F. (2004). Seven new species of Garra (Cyprinidae : Cyprininae) from the Rakhine Yoma, Southern Myanmar. Ichthyological Exploration of Freshwaters, 15(3) : 257-278.

Rainboth, W. J. (1983). Psilorhynchus gracilis, a new cyprinoid fish from the Gangetic lowlands. Proceedings of the California Academy of Sciences, $\mathbf{4 3}$ : 67-76.

Shangningam, B. D. and Vishwanath, W. (2016). Psilorhynchus konemi, a new species of torrent minnow from North-East India (Teleostei : Psilorhynchidae). Ichthyological Exploration of Freshwaters, 27(4) : 289-296. 